\title{
Analysis of Climate Factors on Paddy Production in West Java
}

\begin{abstract}
Faradiba
${ }^{1}$ Department of Physics Education, Universitas Kristen Indonesia. Corresponding Email: faradiba@uki.ac.id

ABSTRACT

The current global climate change is considered difficult to control. The causes of these conditions are climate change, such as temperature, water pressure, humidity and rainfall that occur continuously in all countries. Climate changes conditions directly have an impact on agricultural production, especially paddy. This study aims to determine the impacts of climate change, including temperature, water pressure, humidity, and rainfall on the production of paddy. Specified research locations were West Java Province. This study used secondary data including climate data and paddy production in 2002-2015. This study used a multiple regression analysis method. From the analysis of each variable, it is informed that climate factors have a significant influence on the production of paddy in West Java Province are temperature and humidity
\end{abstract}

Keywords: climate, paddy production, multiple regression

\section{INTRODUCTION}

The agricultural sector is one sector that plays an important role in improving the country's economy. This can be seen from the production produced in the agricultural sector which has become a national product. Production produced in the agricultural sector is strongly influenced by climate change that occurs (Geboren, 2012; Murniati et al., 2017). Climate is closely related to weather patterns that occur in a region. Climate change can occur if climate factors undergo continuous change for decades. The intended climate factor is a case of temperature, air pressure, humidity, rainfall, solar exposure time, wind speed and solar radiation (Porter et al., 2015; Schmidhuber and Tubiello, 2007; Singh, 2012; Turral et al., 2011; Wheeler and Von Braun, 2013).

Temperature is the degree or measure of heat produced by the activity of molecules in the atmosphere. Temperature or air temperature can also be referred to as degrees or measurements of heat or cold based on a certain scale. An ordinary temperature measuring instrument uses a thermometer (Gunarsih, 2004).

Air humidity is defined as the sum of the average yield of water as a whole including steam, water drops and ice crystals that are in the air at a certain time
(Pettigrew \& Whipp, 1993; Neiburger, Edinger \& Bonner, 1973).

Rainfall is the amount of water that falls on a flat surface during a certain period measured in units of height ( $\mathrm{mm}$ ) above the horizontal surface if there is no evaporation, unoffing and infiltration. The rainfall unit is $\mathrm{mm}$, inch (Linsley, 1975). Curah rain is an element of high climatic fluctuations and their effects on crop production significantly (Faradiba, 2020; Kaushik \& Sing, 2008; Nirmala \& Sundaram, 2010; Bari, Rahman, Hussain, 2010).

Climate change which is quite volatile can affect the success rate of production in the agricultural sector. Climate change has a negative effect on the decline in agricultural production (Utami \& Hardyastuti, 2011; D'Aleo \& grube, 2002). The results of the study, the La Nina incident negatively affected rice production in Java. This study proves that climate variations such as drought events have a high impact on dryland crop yields.

It is feared that the existence of climate change will bring serious problems to the sustainability of agricultural development in Indonesia, including, a decrease in productivity and production of agricultural products, the occurrence of degradation of agricultural potential land resources and water availability resulting in a decrease in soil fertility, variability and climate change resulting floods and 
drought, as well as the conversion of functions and fragmentation of agricultural land (Surmaini, Runtunuwu and Las, 2011).

In Indonesia, the determining factor for the growing season is the availability of water which is influenced by rainfall. Even though annual rainfall is high, even in some areas irrigation network facilities are available, the planting period in most food crop production areas still depends on the conditions of seasonal rainfall reception (Hidayati, Imron \& Dasanto, $2010)$

Rainfall is one of the elements of climate that plays a significant role in the availability of water for plants. High and low rice production cannot be separated from the availability of water for plants. It was also revealed that the potential yield of rice plants is closely related to the guarantee of water availability during the growing season. This study aims to look at the influence or relationship between climate factors, namely temperature, air pressure, humidity and rainfall on increasing agricultural production in West Java Province.

\section{METHOD}

In this study, the location that took as a climate analysis was the province of West Java. The data used in this study are secondary data taken from the annual publication of the Central Statistics Agency of West Java Province. Climate data used are temperature, air pressure, humidity and rainfall data. The data is in the form of annual data which he took from 2002 to 2015. For agricultural production using data from annual production of paddy from 2002 to 2015.

Data were analyzed using multiple regression analysis for each climate factor for agricultural production:

a. Multiple regression method

Regression Method is a method which is an integration of a simple linear regression method. Linear regression method is used to see how the multiple variables be $\mathrm{b}$ as against a dependent variable.

For the purpose of analysis, the independent variable will be declared with $\mathrm{X}$ while the independent variable will be expressed as $\mathrm{Y}$. The form of the multiple linear regression model is

$$
\mathrm{Y}=\mathrm{a}+\mathrm{b} 1 \mathrm{X} 1+\mathrm{b} 2 \mathrm{X} 2+\ldots .+\mathrm{b} n \mathrm{Xn}(1)
$$

b. The coefficient of determination $\left(\mathrm{R}^{2}\right)$

The coefficient of determination $\left(\mathrm{R}^{2}\right)$ is used as information regarding the suitability of the model. The coefficient of determination between 0 to 1 . Named the coefficient of determination because $R^{2} \times 100 \%$ of the variation that occurs in the independent variable $\mathrm{Y}$ can be explained by the independent variable $\mathrm{X}$ with the linear regression of $\mathrm{Y}$ over $\mathrm{X}$. The magnitude of the price of the coefficient of determination is in the range $0<\mathrm{R} 2<1$. To ensure the type of relationship between variables with reference to Table 1 .

Table 1. Coefficient Interpretation

\begin{tabular}{|c|c|}
\hline Coefficient interval & Category \\
\hline $0.80-1.00$ & Very strong \\
\hline $0.60-0.79$ & Strong \\
\hline $0.40-0.59$ & Enough \\
\hline $0.20-0.39$ & Low \\
\hline $0.00-0.19$ & Very low \\
\hline
\end{tabular}

\section{c. F Test (Model Test)}

The $\mathrm{F}$ test or model test is used to see how the interrelationships for all the independent variables that exist together with the dependent variable. This $\mathrm{F}$ test is used to see whether the model is generated from the data that is owned or not.

d. T Test (Partial Test)

$\mathrm{T}$ test or partial test is used to see the effect of each independent variable individually on the dependent variable.

\section{RESULT AND DISCUSSION}

Based on data from the Central Statistics Agency (BPS), data on four climate factors and annual agricultural production data for West Java Province are Table 2. 
Table 2. Climate Factor Data for 2002 - 2017

\begin{tabular}{|l|c|c|c|c|c|}
\hline Year & $\begin{array}{l}\text { Tempera- } \\
\text { ture }\left({ }^{\circ} \mathrm{C}\right)\end{array}$ & $\begin{array}{c}\text { Humidity } \\
(\%)\end{array}$ & $\begin{array}{c}\text { Barometric } \\
\text { Pressure } \\
(\mathrm{mb})\end{array}$ & $\begin{array}{c}\text { Rainfall } \\
(\mathrm{mm})\end{array}$ & $\begin{array}{c}\text { Agricultural } \\
\text { production } \\
(\text { million } \\
\text { tons })\end{array}$ \\
\hline 2002 & 23,558 & 76,500 & 922,317 & 188,633 & 8,256888 \\
\hline 2003 & 23,558 & 75,667 & 922,333 & 156,383 & 9,299506 \\
\hline 2004 & 23,533 & 77,167 & 922,275 & 161,033 & 9,480493 \\
\hline 2005 & 23,400 & 82,000 & 922,225 & 190,242 & 9,787217 \\
\hline 2006 & 23,467 & 79,583 & 922,317 & 141,783 & 9,418572 \\
\hline 2007 & 23,517 & 81,000 & 922.133 & 186,125 & 9,914019 \\
\hline 2008 & 23,175 & 78,667 & 922,542 & 166,750 & 10,111064 \\
\hline 2009 & 23,367 & 78,750 & 922,925 & 174,800 & 10,924508 \\
\hline 2010 & 23,308 & 83,500 & 922,383 & 322,367 & 11,271064 \\
\hline 2011 & 23,375 & 76,250 & 922,100 & 149,058 & 11,180651 \\
\hline 2012 & 23,400 & 75,750 & 923,050 & 209,225 & 11,753612 \\
\hline 2013 & 23,458 & 77,917 & 923,075 & 223,450 & 11,538472 \\
\hline 2014 & 23,392 & 77,167 & 923,733 & 199,000 & 11,644899 \\
\hline 2015 & 23,533 & 74,500 & 924,117 & 184,675 & 10,856438 \\
\hline
\end{tabular}

Source: Badan Pusat Statistik.

From the annual data, the independent variables are four climate factors. X 1 for temperature data, X 2 for humidity data, X 3 for air pressure data and $\mathrm{X} 4$ for rainfall data. The dependent variable is the product of production.

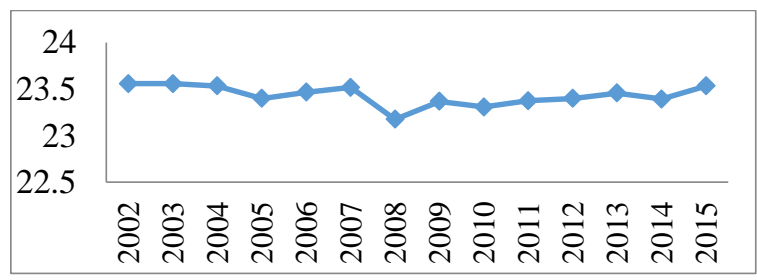

Figure 1. West Java Province Temperature 2002 $2015\left({ }^{\circ} \mathrm{C}\right)$

Figure 1. Shows that in 2008 the average temperature for a year was below 23 o C. Temperature in the last 8 years indicated an increasing trend. In the period of 2002-2016, the Hydrometeorology disaster in Indonesia jumped sharply such as floods, tornadoes and

landslides. The disaster was inseparable from the current climate change which rose 1 degree celsius (earth temperature) compared to the industrial revolution. The implication is extreme weather, the impact of extreme weather is disasters such as floods (Mahawan, 2019) .

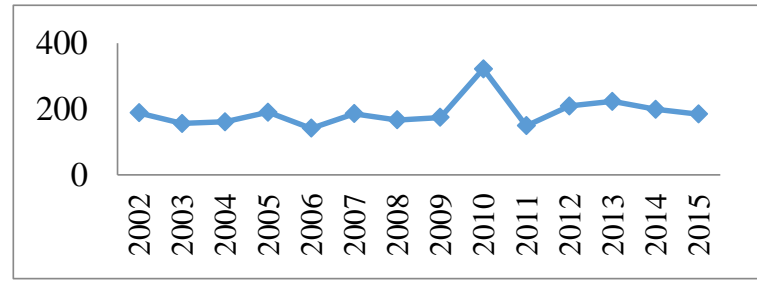

Figure 2 . Air Humidity, West Java Province , 2002 $2015(\%)$

Figure 2. Shows that air humidity in 2010 reached its maximum point during the observation data period, whereas during the last 5 years it showed a declining trend.

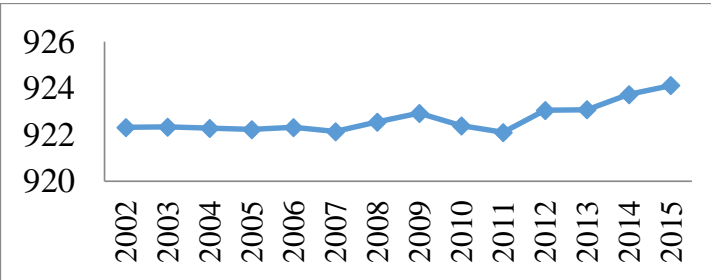

Figure 3. West Java Province Air Pressure in 2002 $2015(\mathrm{mb})$

Graph 3. Showing air pressure during the observation period shows an increasing trend. Significant improvement occurred during the last 5 years. Graph 4. Shows the highest rainfall in2010, while other years during the observation period showed a relatively stable number. 


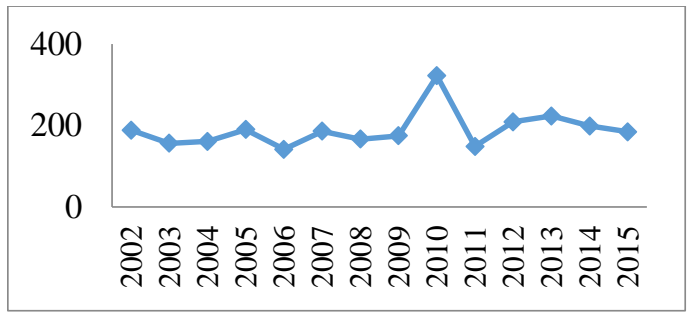

Figure 4. Air Humidity, West Java Province, 2002 $2015(\%)$

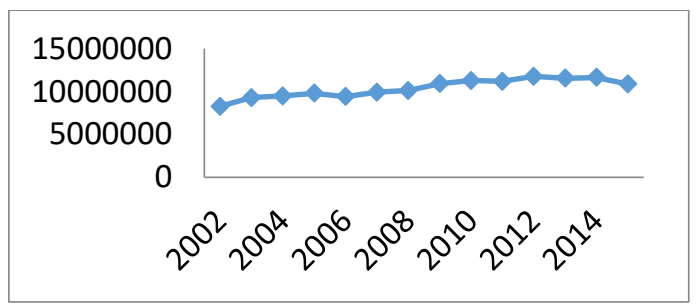

Figure 5. Paddy Rice Production West Java Province 2002 - 2015 (Tonnes)

In Figure 5. Shows the trend of the practice of rice production which is training to increase. Rice is the main ingredient for consumption of Indonesian society, along with the increasing population of the population of West Java Province, it is expected that an increase in rice production will also increase.

From the regression analysis that combines between variables, information is obtained that climate variables that have a significant influence on paddy production in West Java Province are Humidity $\left(\mathrm{X}_{1}\right)$ and Air Temperature $\left(\mathrm{X}_{3}\right)$.

Table 3 Summary Model

\begin{tabular}{|c|c|c|c|c|}
\hline Model & $\mathrm{R}$ & $\mathrm{R}$ Square & $\begin{array}{c}\text { Adjusted R } \\
\text { Square }\end{array}$ & $\begin{array}{c}\text { Std. Error of the } \\
\text { Estimate }\end{array}$ \\
\hline 1 & $.726 \mathrm{a}$ & 526 & .440 & .799180712 \\
\hline \multicolumn{4}{|c|}{ a. Predictors: (Constant), $\mathrm{X}_{3}, \mathrm{X}_{1}$} \\
\hline
\end{tabular}

From the above table are informed that the correlation/relationship (R) of 0.726 and a coefficient of determination $\left(\mathrm{R}^{2}\right)$ of $0.526 . \mathrm{R}^{2}$ obtained, it can be interpreted that influence bebar variables (temperature and humidity) of $52.6 \%$, while the rest influenced by other variables.
Table 4. Anova

\begin{tabular}{|c|c|c|c|c|c|c|}
\hline \multicolumn{2}{|c|}{ Model } & $\begin{array}{c}\text { Sum of } \\
\text { Squares }\end{array}$ & df & $\begin{array}{c}\text { Mean } \\
\text { Square }\end{array}$ & F & Sig. \\
\hline \multirow{2}{*}{1} & Regression & 7,810 & 2 & 3,905 & \multirow{2}{*}{6,114} & \multirow{2}{*}{0.016} \\
\cline { 2 - 6 } & Residual & 7,026 & 11 & .639 & & \\
\cline { 2 - 5 } & Total & 14,836 & 13 & & & \\
\hline
\end{tabular}

In the above table can be seen significant effect (significant) between the temperature variable $\left(\mathrm{X}_{1}\right)$ and humidity $\left(\mathrm{X}_{2}\right)$ to variable production of rice paddy $(\mathrm{Y})$. From the output it can be seen that the F count is 6.114 with a significance level / probability of $0.016<0.05$, then the regression model can be used to predict the variable paddy production.

Table 5 . Coefficients

\begin{tabular}{|c|c|c|c|c|c|c|}
\hline \multirow{2}{*}{ Model } & \multicolumn{2}{|c|}{$\begin{array}{c}\text { Unstandardized } \\
\text { Coefficients }\end{array}$} & $\begin{array}{c}\text { Standardized } \\
\text { Coefficients }\end{array}$ & \multirow{2}{*}{$\mathrm{t}$} & \multirow{2}{*}{ Sig. } \\
\cline { 3 - 6 } & $\mathrm{B}$ & Std. Error & Beta & & \\
\hline \multirow{2}{*}{1} & $($ Constant $)$ & $-778,661$ & 331,609 & & $-2,348$ & .039 \\
\cline { 2 - 7 } & $\mathrm{X}_{1}$ & $-4,569$ & 2,038 & -.465 & $-2,242$ & .477 \\
\hline & $\mathrm{X}_{3}$ & .971 & .357 & .565 & 2,724 & .20 \\
\hline
\end{tabular}

In coeficients table, in column B row constant (a) is -778.66, while the value of $\mathrm{X}_{1}$ and $\mathrm{X}_{3}$ amounted to 4.569 and 0.971 , so the equation can be written as follows :

$$
\begin{aligned}
& Y=a+b_{1} X_{1}+b_{3} X_{3} \\
& Y=-778.66-4,568 X_{1}+0.971 X_{3}
\end{aligned}
$$

From the table above it can also be known the $t$ value of -2.2242 and 2.724 with a significance value of $0.000<0.05$, it can be informed that there is a significant (significant) influence between the temperature $\left(\mathrm{X}_{1}\right)$ and air humidity $\left(\mathrm{X}_{3}\right)$ variables on the variable Saaawah rice production $(\mathrm{Y})$.

\section{DISCUSSION}

Rice is an important commodity for Indonesia, considering that most of the Indonesian people consume rice as its main foodstuff. In 2018, Indonesia as an agricultural country imports rice to meet domestic needs. This is a big note for the government, because in the midst of the great potential of the Agriculture Sector, Indonesia must import rice. Rice is also a prestigious product for a country, because if we always import indirectly the country depends on the fate of millions of its people to other countries. 
As one of the largest rice producing provinces in Indonesia, West Java Province has a trend of fluctuating rice production during 2008-2015. The condition is inseparable from the climatic conditions that occur in West Java Province. In this study, the authors examine how the effects of climate change, among others: temperature, water pressure, humidity, and rainfall on rice production.

From the results of the calculation of temperature and humidity have a significant effect on rice production. On the one hand, the other two variables are not significant. Air temperature and humidity can be known through the latest trends. Especially if local agencies can predict the temperature and humidity levels of the air that will occur in the coming periods. This is intended so that farmers can know in what month should plant and harvest. As well as the selection of what commodities should be chosen when extreme weather conditions occur.

As a sexy commodity, the policy should be carried out centrally and comprehensively, so that the implemented policy can be implemented to all farmers through the command of the Ministry of Agriculture / Horticulture and Food Crops Office of West Java Province. These efforts can be realized through extension of the planting period (in accordance with the results of the climate projection from $\mathrm{BMKG}$ ) to farmer groups. At the same time aid seeds are selected in accordance with future climate conditions, so that rice production can be abundant. Assistance to farmers can also be pesticides to attack pests and plant diseases (HPT) in accordance with the latest HPT growth due to the current climate.

In advanced research, it is better to use more updated data, considering that until now rice production data are only available in 2015. 2016-2019 rice production data can be estimated by considering public consumption, existing stock in BULOG, and rice imports. Further researchers can also add the variables of pests and diseases of the dominant plants that attack during the observation period.

\section{CONCLUSION}

From the climate factors analyzed there are 2 variables that have a significant effect and 2 other variables that have no significant effect. Variables that have a significant influence include temperature and humidity variables. All four observational variables if analyzed simultaneously, do not show significant results.

\section{REFERENCES}

1. Bari, S. H., Rahman, M. T., Hussain, M. M., Ray, S., 2015. Forecasting monthly precipitation in Sylhet city using ARIMA model. Civil and Environmental Research, 7(1), 69-77.

2. $\quad$ BPS., 2015. West Java in Figures. (Quoted from several years of regional publication in BPS figures West Java Province)

3. D'Aleo, J. S., Grube, P. G., 2002. The oryx resource guide to El Niño and La Niña. Greenwood Publishing Group.

4. Faradiba, F., 2020. Analisis Pola Curah Hujan Terhadap Produktifitas Tanaman Padi Sawah di Provinsi Jawa Barat. EduMatSains: Jurnal Pendidikan, Matematika dan Sains, 4(2), 139152.

5. Gunarsih, A., 2004. Klimatologi Pengaruh Iklim Terhadap Tanah dan Tanaman. Jakarta: Bumi Aksara.

6. Hidayati, R., Impron, \& BD., 2010. Dasanto. Development of a semidynamic plant calendar for the preparation of alternative cropping patterns with minimum climate risks based on ENSO characteristics. Research Report -IMHERE B2C Research Grant.

7. Kaushik, I., \& Singh, S. M., 2008. Seasonal ARIMA model for forecasting of monthly rainfall and temperature. Journal of Environmental Research and Development, 3(2), 506-514.

8. Linsley Jr, R. K., Kohler, M. A., \& Paulhus, J. L., 1975. Hydrology for engineers.

9. Neiburger, M., Edinger, J. G., \& Bonner, W. D., 1973. Understanding our atmospheric environment.

10. Nirmala, M., \& Sundaram, S. M., 2010. A seasonal ARIMA model for forecasting monthly rainfall in Tamilnadu. National Journal on Advances in Building Sciences and Mechanics, 1(2), 43-47.

11. Pettigrew, A., \& Whipp, R., 1993. Understanding the environment. Managing change, 2(1), 65-76.

12. Surmaini, E., Runtunuwu, R., Las, I.., 2011. Agricultural Sector Efforts in Dealing with Climate Change. Agricultural Research and Development Journal 30 (1): 1-7.

13. Utami, A. W., \& Hardyastuti, S., 2011. El Nino, La Nina, dan penawaran pangan di Jawa, Indonesia. 